Dušan Aničić ${ }^{1}$

Jugoslav Aničić ${ }^{2}$

University "Union-Nikola Tesla", Faculty of Economics and Finance, Belgrade

Vuk Miletić ${ }^{3}$

The College of Academic Studies "Dositej", Belgrade
ORIGINAL SCIENTIFIC ARTICLE doi:10.5937/ekonomika2001037A

Received: September, 25. 2019.

Accepted: December, 21. 2019.

\title{
COST MANAGEMENT EFFICIENCY FACTORS OF ENTERPRISES IN SERBIA
}

\begin{abstract}
Increased complexity of business operations, fast market and technological changes and global competition demand a quick and adequate answer from enterprises' management structures. Reliable and efficient cost accounting system provides a secure basis for making not only short-term, but strategic managements' decisions, as well. Assumptions for an increase of cost management efficiency are better interconnection between financial and management accounting, better control of cost types and cost centers, more reliable information for an alternative business decision making, support to investments control and strategic planning, impact on the motivation of employees and other. Seizing and keeping of enterprise's competitive position is no longer possible without active cost management policy. Research in this paper has shown that enterprises from Serbia's economic sector can significantly improve its business performance and competitiveness through advancement of cost accounting system.
\end{abstract}

Key words: cost management, enterprise, efficiency factors, competitiveness, Serbia

JEL classification: D24, D25, L22, L23

\section{ФАКТОРИ ЕФИКАСНОСТИ УПРАВЉАҢА ТРОШКОВИМА ПРЕДУЗЕКА У СРБЈИ}

\begin{abstract}
Апстракт
Нарасла сложеносии иослована, брзе иржишне и иехнолошке иромене и глобална конкурениија захиеввају брз и адеквайан одговор уиравльчких сиирукйура ирредузећа. Поуздан и ефикасан сисием обрачуна иирошкова ирружа сигурну основу за доношене не само крайкорочних, већ и сираитегіиских

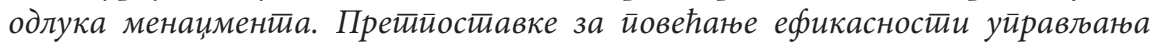

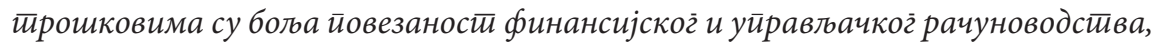

\footnotetext{
${ }^{1}$ ajugoslav@yahoo.com, ORCID ID https://orcid.org/0000-0003-3467-7071

2 dusan.anicic@yahoo.com, ORCID ID https://orcid.org/0000-0003-1201-0532

${ }^{3}$ vuk.miletic88@gmail.com, ORCID ID https://orcid.org/0000-0002-6250-6803
} 


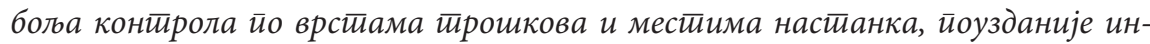
формације за алитернатиивно йословно одлучиване, йодрика конитроли инвес-

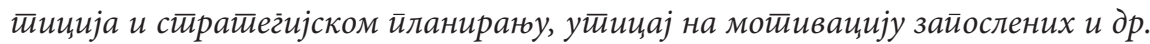
Освајате и одржаваюе конкуренйске йозиције иредузећа више није могууће без акиивне йолииике уйрављана йрошковима. Истираживане у овом раду је йоказало да йредузећа из иривредног секитора Србије могу значајно йоболиайи своје йословне иерформансе и конкуренииносии унаиређенем сисиемма обрачуна ироикова.

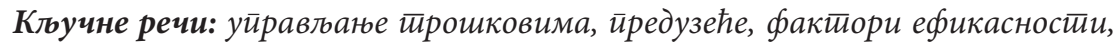

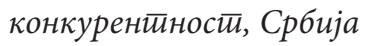

\section{Introduction}

Two basic strategies for realization of competitive advantages are cost leading strategy and differentation strategy. The goal of cost leading strategy is upbuilding and keeping of competitive advantage on market thanks to lower costs in comparison with competition. Costs are a factor on which enterprises can influence to a large degree, and thus they represent a starting point for realization of positive result of business, i. e. profit. Lower costs enable forming of lower selling prices in comparison with competition and, on that basis, realization of higher profit. For a successful implementation of this strategy, organizational structure with a high degree of specialization and standardization, as well as centralization and functional grouping of units, is necessary.

In modern business, management is obsessed with business-financial efficiency and effectiveness of enterprises' acitivities, so it is because of that directed to accounting as the main source of information for decision making. In Serbia, application of modern cost accounting methods is still in its infancy, but some experience, methods and practice are being taken over from enterprises from developed countries. Obstacles for a faster adoption of modern methods are often domestic regulations, rules on capital market, tax regulations, inertness of accounting profession and insufficient significance which is given to these issues by enterprises' management. Because of mentioned, cost accounting concept is often set in order to be appropriate for classical accounting principles and tax regulations, and not to objectives of cost accounting which are considerably wider than only providing cost price for the needs of balancing of output inventories.

Research in this paper has a goal to determine which factors have the biggest impact on cost management efficiency in enterprises viewed from managers' corner, on one hand, and from accounting workers, on the other. Through research, we want to identify the largest limitations and problems in application of modern cost accounting methods and, on the basis of obtained results, we want to recommend possible solutions and improvements in this area. The significance of the research is particularly important taking into account the fact that the application of international standards in areas of accounting and financial reporting in Serbia has started just in 2004. 


\section{Cost management concept}

Increased complexity of business operations caused by fast technological and market changes and diversification of business-financial activities of enterprises caused growing application of accounting information in enterprises. Demands to increase productivity and sturdy cost control caused by intensified competition, comprehension of vital role of planning and control in managing, decentralization of management and establishment of flexible organizational structure of enterprises lead in the same direction.

Enterprises operate in turbulent surrounding, with sudden and deep changes with insecure and uncertain perspective. Competitors on today's market know each other better, and methods of their functioning are becoming more and more equalized. Flexibility, innovativeness and continuous improvement of business operations are elements which are becoming a component of strategic approach to competitive advantage creation. Success in such surrounding achieve only those enterprises which are faster in adapting to new changes on market. Modern organizations provide enterprises' management a more efficient usage of existing capacities and rationalization of business operations' expenses.

Contemporary information systems enable adequate monitoring of processes costs, and information about their occurrence and trends enable management to timely react and make business decisions. Rationalization of costs enables minimization of costs along with realization of desired result, which, except for business and financial indicators, includes and subjective feeling of customer satisfaction. Cost management is a special way of enterprise and business operations management which the greatest importance, in organization's goals achievement, commits to costs optimization.

Dynamic changes of external surrounding impose to enterprises a strategic way of thinking. Changes create a problem, but they can become chances if enterprise's management is aware of its position, its movement direction and the consequences of wrong strategy implementation. Running of the company has to be information supported and strategically oriented. Capability to obtain and use resources in a way to utilize chances from surrounding and avoid its threats is of central importance for organization's prosperity (Wilson \& Gilligan, 2003).

Cost management contributes to global competitiveness of enterprises and to continuous improvement of business operations (Agrawal, et all, 1998). Cost management is also defined as philosophy, attitude (mission) and a series of techniques whose goal is to create a greater value with lower costs (Hilton, et all, 2000). Cost management represents a range of methods that can be used on an individual level in order to support certain decision or organization's management as a whole (Škrtić, 2005). According to Groth \& Kinney (1994), the purpose of strategic cost management is production of continous information cycle on activities in short and long term, in order to increase value in the eyes of customers and reduce costs.

Expenses have suffered, in the last decades, significant changes in its structure and in its general role, as well (Malinić et all, 2018). Organization's profit and its competitiveness on market depend on management's capability to recognize which are the key factors that provide superior performance - better quality, lower costs, higher quality service (Micić, Arsić, 2010).

Cost leading strategy implies that enterprise function efficiently whereby costs have a central role. Lower costs create possibility to form lower selling prices in comparison 
with competition and, on that basis, realization of higher profits. Cost leading strategy requires organizational structure with a high degree of specialization, formalization, standardization, centralization and a functional grouping of units. On the other hand, differentiation strategy requires an enterprise to be flexible, innovative and to have a segmented market approach (Micić, Arsić, 2010).

Cost accounting implies different techniques and approaches when valuating inventories, determining and monitoring costs by their location, transferring from auxiliary to the main cost centers, as well as linkage of costs with their drivers - products and services (Todorović, 2009). Traditional cost accounting models became unreliable for cost management and business decisions making, so enterprises are forced to apply modern cost accounting models (Antić, Novićević, 2011).

Traditional techniques of cost accounting (although such techniques are still widely used), are a subject of numerous critiques because of its inflexibility and impossibility to keep up with a change of business surrounding. Traditional accounting techniques with full costs, whereby general costs are "absorbed" in production by using some basis (for example, machine's work hours or direct work), were developed in times when direct work, raw materials and machine work were the most important inputs in production process (Aničić, Popović, 2015).

In order to cost accounting be efficient, it has to be tailored according to unique nature of business process in enterprise. There is no cost accounting system which will be superior in all possible situations. It can be said that economy and efficiency of cost accounting are determined by enterprise's business process nature and types of information that its management needs (Milićević, 2000).

Cost accounting supplies enterprise's management with necessary tools for the needs of planning and control of business activities, improvement of quality and efficiency of functioning and making decisions, both routine and strategic ones. Collection, presentation and analysis of information that refer to costs and outputs of an enterprise should enable management to successfully execute numerous tasks that are put in front of it (Hammer et al, 1994).

In future, a growing usage of management accounting means can be expected. Some of them are: budgeting, standard costs accounting system, responsibility accounting, contribution analysis and differential approach in creation of relevant data for the needs of making individual decisions. These tools, for enterprise management, have a much bigger significance in comparison with double bookkeeping and preparation of conventional financial statements (Horngren, et all, 1994).

Numerous authors are in their works pointed to information limitations of traditional cost accounting systems. Cooper \& Kaplan (1988), emphasize that decisions must be based on differential or/and incremental costs (and revenues) whose constructions vary in accordance with the nature of problem which is being solved. Traditional cost accounting systems are primarily created to provide information for the needs of external financial reporting in times when production technologies were, before all, labor-intensive (Kaplan, 1988).

In modern conditions of functioning, costs represent a measure of quality because many things and processes in enterprise depend on them. Integrated cost management in modern conditions of functioning where competition fight happens not only among enterprises, but among value chains as well, implies combined and mutual usage of more 
modern concepts, accounting systems, methods and techniques for cost management in order to monitor, control, analyze and inform on costs within the value chain (Malinić, Jovanović, 2011). The key of integrated cost management is hidden in synergy effect, i. e. achievement that the whole is bigger than the sum of individual parts.

For a successful application of any cost management model in an enterprise, it is necessary to accomplish that all organizational units in it work as a team, starting from top management, over finances, accounting, production, marketing and other. The implementation of cost management model implies objectives definition, identification of activities that result in added value, knowing financial and nonfinancial indicatiors of functioning. Thereby, every organizational part has to carefully analyze its activities and costs, as well as the time in which the application will be executed.

Table 1: Strategic role of costs

\begin{tabular}{|l|c|c|}
\hline & Differentiation strategy & Cost leading strategy \\
\hline Standard costs role in assessment of performances & Not very significant & Very significant \\
\hline $\begin{array}{l}\text { Concepts' significance (such as flexible planning) for } \\
\text { production costs control }\end{array}$ & Moderate to low & High to very high \\
\hline Perception (acceptance) of plans realization significance & Moderate to low & High to very high \\
\hline Marketing costs' analysis significance & Critical for success & Often not formalized \\
\hline $\begin{array}{l}\text { Product cost significance (as an input in making decision } \\
\text { on prices) }\end{array}$ & Low & High \\
\hline Competitors' costs analysis significance & Low & High \\
\hline
\end{tabular}

Source: Shank, J., Govindarajan, V. (1993) Strategic Cost Management: The New Tool for Competitive Advantage, Free Press, New York

\section{Basic features of cost accounting in enterprises in Serbia}

In countries with developed market economy, merciless competition, with clearly defined positions of agents, i. e. owners and managers which among themselves agree on system of authority and responsibility, is dominant. In such business ambient management is necessarily obsessed with business-financial efficiency and effectiveness of enterprise, so it is hence directed to accounting as the main source of information for making decisions. In Serbia, such ambient is still in its infancy and cost accounting is being developed by models from developed countries.

In modern conditions of functioning, flexible financial strategy which will provide adaption of enterprise to changes in dynamic surrounding, with minimal costs and maintenance of high competitiveness, is necessary. Flexibility of an enterprise is its capability to quickly and with minimal costs avoid threats and utilize opportunities, and managing of financial flexibility is in the function of maximazation of enterprise's value. Efficiency of investment in a certain project is generally assessed by two groups of methods: static and dynamic methods (Begović, et al.).

What differs good from weak business strategy is managers' capability to foresee movements that enable creation of sustainable competitive advantage with which 
enterprise has good perspectives to achieve above-average profitability in chosen frames for functioning. Because of that, a particular attention must be paid to important aspects of products and services competitive advantage creation. Adoption and application of international standards of quality is especially required for small enterprises which are subcontractors or collaborators of big systems. Also, there are numerous specificities depending on business area in which enterprise is functioning, such as industry production, construction industry, trade and similar.

Low costs strategy is an endeavor of enterprise to minimize both total and costs per product and service unit. Selling price is formed on branch level and enterprise accepts it as a given value, so profit realization is dependent on the height of costs. Enterprise that has lower costs in comparison with competition, realizes higher profits and enables possibilities for investing and keeping of competitive advantage. In addition, lowering of costs must not lead to lowering of product's perceived quality.

Preconditions for successful development of an enterprise and application of international standards are stable conditions of functioning, low inflation, mild changes in currencies' exchange rates, existence of active assets and liabilites markets, development of securities market and other. As far as Serbia is concerned, problems with application of international standards are high inflation in transition period, instability of exchange rates, often changes in legislative, dominant application of purchase value model (neglecting of fair value model), undeveloped securities market, insufficient significance that is given to standards application which is revealed in the lack of literature that is dealing with them, insufficient representativeness in high schooling, non-existence of trainings and incentives by the state.

Domestic law rules, achieved level of economic development, prescribed or nonprescribed form of accounting and financial statements, rules on capital market, tax regulations and other also affect a delayed and slow process of implementation and harmonization with international standards (Rodić, et all, 2011). Some other problems are complexity of integration of the standards into domestic regulations, impact of domestic tax regulations, often changes and amendments of standards and problems with their interpretation, slow or minimal changes of culture in certain countries and other.

Application of IFRS (International Financial Reporting Standards) is obligatory in Serbia since 2004, and for banks and other financial organizations since 2003. Obligatory application of these standards is introduced with an aim to harmonize our accounting system with generally accepted achievements in this area. However, in many small and even medium enterprises the functions of management and ownership are not separated, i. e. owner is oftentimes a manager of an enterprise, at the same time. Such conditions do not create favourable climate for management accounting development, nor modern cost accounting concepts. These enterprises, as a rule, rely on traditional cost accounting methods, so all defects of those methods reflect on their results. That intensifies problems related to illiquidity, as well as shutting down of large number of small enterprises, especially having in mind stronger and stronger competition in all areas of business.

On the other hand, inertness, i. e. unwiligness of accounting profession to adopt and apply modern concepts in monitoring and accounting of costs is also present. Costs concept is often set in order to be appropriate for classical accounting principles and tax regulations, and not to objectives of cost accounting which are considerably wider than only providing cost price for the needs of balancing of output inventories. In Serbia, 
according to current legal regulations, there is no obligation of certification of accounting staff, which is a big step back in the development of accounting profession as a whole.

Important shift in profession development was made by education and certification of accountants and auditors in accordance with programs of renowned world's accounting institutions. In Serbia it is necessary to raise professional culture and by upgrading the knowledge of managers and accountants, among which has to exist mutual trust which is, in a modern business world, an important precondition for successful enterprise management.

Legal entities and entrepreneurs, which are in production business in Serbia, are obliged to, in their bookkeeping, have class 9 - Accounting of costs and outputs which deals with (Petrović, et al, 2015): distribution of costs onto cost centers and outputs, connection of revenues with corresponding outputs, as well as with determination of business result on the level of business units - profit centers and determination of business result for whole enterprise by using sold outputs cost method. Accounting of costs and outputs provides data on:

1. Cost price of products and services that enterprise produces and sells;

2. Changes in inventories' value (final in comparison with initial);

3. Amounts of deviations from predicted (normal) functioning conditions in consumption, employment and efficiency;

4. Business results on business units level and on the level of an enterprise as a whole.

Very significant area related to costs is managing of projects' costs for which project directors, in cooperation with accounting and financial experts, are in charge of. During project's realization, different types of costs appear, some of which are direct (can be easily linked with making of product or providing of service on project), and others are indirectly linked with project's implementation, and project directors have a very small impact on their height. Different methods and techniques for costs assessment are being used, such as (Schwalbe, 2015): analogous estimate, bottom-up assessment, parametric modeling of resources cost rates, suppliers' offers and reserves analysis, software for project management.

The most common reasons for wrong estimates of project's costs are (De Marco, 1982): estimates are conducted quickly, lack of experience in conducting estimates, underestimation of certain types of costs, endeavor to obtain a big contract or internal means. Considering the fact that many projects are not conducted in accordance with plans, new or modified estimates of costs are often necessary in order to enact alternative solutions. Problems are even more complex in organizations which simultaneously realize more projects or investments as a group of interconnected activities united in a portfolio.

Having in mind the complexity of business environment in which enterprises function, it is obvious that additional attention has to be committed to the questions of choosing, realization and estimate of investment projects. That primarily refers to the project's financial construction part because of interest rates' height, high accompanying crediting expenses, currency clauses in contracts, mortgage support of credits and other. On the other hand, enterprises do not have enough of own (internal) funds to finance investment projects, so they are forced to accept unfavorable conditions under which are borrowed funds are obtained. Many significant costs of projects are underestimated or even overlooked, which later leads to different financial and business problems. 


\section{Methodology}

Research for the needs of this paper was conducted in the period from December 2018 to March 2019 on the sample of 48 examinees, half of which is from big enterprises, and the other half is from small and medium enterprises. Division on small and medium, on one, and big enterprises, on the other hand, was carried out in accordance with current Law on Accounting of the Republic of Serbia. Examinees structure in sample was made of managers, on one, and people employed on the jobs of accounting and finances, on the other hand. All examinees have a college degree (faculties) and work experience longer than 3 years on jobs of accounting and finances.

Examinees assessed impact of the following factors on cost management efficiency in enterprises in Serbia: competence of accounting staff, management's comprehension, competition's influence and legal and internal accounting regulation. The answers are statistically processed in program SPSS, tested by Kramer's test, and significance of statistical differences of answers of the two groups of examinees are tested by Hi square test.

From Table 2 it can be seen that the largest number of examinees from big enterprises (15) work on the function of manager, while the largest number of examinees from small and medium enterprises (13) work on the jobs of accounting and finances.

Table 2: Sample's structure considering the type of job on which examinee works on and the size of the enterprise (Crosstabulation)

\begin{tabular}{|c|c|c|}
\hline \multirow{2}{*}{ Type of job } & \multicolumn{2}{|c|}{ Enterprise size } \\
\cline { 2 - 3 } & Big & Small and medium \\
\hline Accounting and finances & 9 & 13 \\
\hline Manager & 15 & 11 \\
\hline Total & 24 & 24 \\
\hline
\end{tabular}

Source: Author's research

\section{Discussion and the results of the research}

From Table 3 it can be noticed that the measures of mean averages of factors' assessments (Competence of accounting staff, Management's comprehension, Competition's influence and Legal and internal accounting regulation) are higher in comparison with theoretical average $(\mathrm{AS}=3)$.

Table 3: Factors expressiveness

\begin{tabular}{|c|c|c|c|c|c|c|}
\hline Factors & $\begin{array}{c}\text { Theor. } \\
\text { min }\end{array}$ & $\begin{array}{c}\text { Theor. } \\
\max \end{array}$ & Empirical min & $\begin{array}{c}\text { Emp. } \\
\max \end{array}$ & AS & SD \\
\hline Competence of accounting staff & 1 & 5 & 3.00 & 5.00 & 3.979 & 0.668 \\
\hline Management's comprehension & 1 & 5 & 2.00 & 5.00 & 3.979 & 0.934 \\
\hline Competition's influence & 1 & 5 & 2.00 & 5.00 & 3.583 & 0.919 \\
\hline $\begin{array}{c}\text { Legal and internal accounting } \\
\text { regulation }\end{array}$ & 1 & 5 & 2.00 & 5.00 & 3.458 & 1.031 \\
\hline
\end{tabular}

Source: Author's research 
The largest number of people employed on jobs of accounting and finances (13) and on management positions (14) assess the factor Competence of accounting staff with a mark 4 (Table 4 and Graph 1).

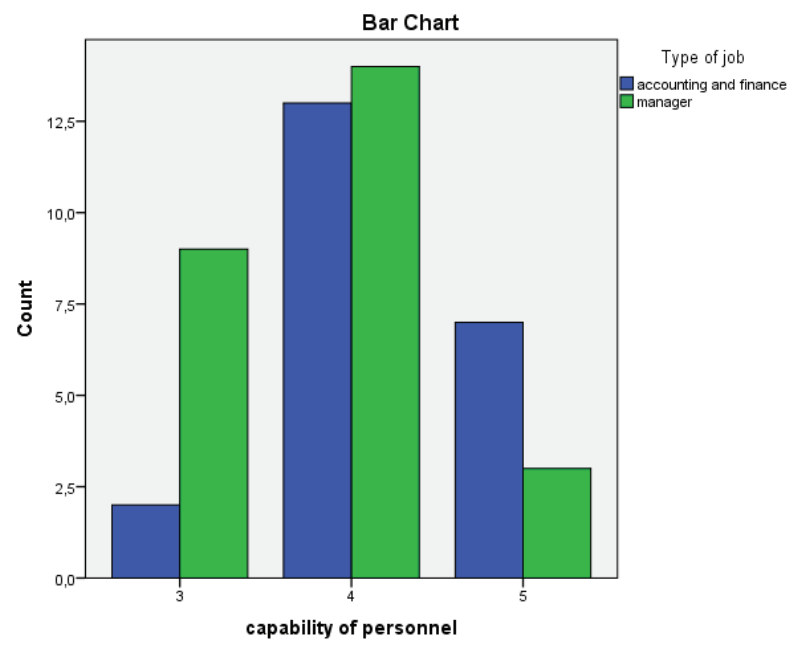

Graph 1: Distribution of examinees' answers in assessment of the factor Competence of accounting staff considering the type of job

Table 4: Differences between examinees in assessment of the factor Competence of accounting staff considering the type of job ( $X^{2}$ test)

\begin{tabular}{|c|c|c|c|}
\hline & Value & df & Statistical significance \\
\hline Pearson's & 5.799 & \multirow{2}{*}{2} & 0.055 \\
\cline { 1 - 2 } Kramer's V & 0.348 & \\
\cline { 1 - 2 } Contigency coefficient C & 0.328 & \\
\hline
\end{tabular}

Statistically significant differences $\left(X^{2}=5.799, \mathrm{p}>0.05\right)$ in assessment of the factor Competence of accounting staff considering the type of job done by examinee were not determined (Table 4). Kramer's indicator is $\mathrm{V}=0.348$, which indicates medium interconnection between variables. Type of job does not affect differences in competence of accounting staff, considering that for all variables Sig $>0.05$, along with existence of medium interconnection between variables.

Because of going through the transition period with delay in comparison with other countries, Serbia was also late with the introduction of international financial reporting standards as a whole, and thus in the area of application of modern concepts from management accounting domain. Competence of people who do accounting jobs in Serbia is not legally defined which left the space for incompetent people to do these jobs, especially in small enterprises and accounting agencies. Changes of legal and by-law regulations and mismatch with professional regulative, embodied in IFRS, are present. All that has a negative effect on possibilities to apply modern cost accounting in enterprises. In this research, managers have also gave a big importance to competence of accounting 
staff and their impact on cost management efficiency. Positive facts are increasing in opening of the economy and endeavor to go out to developed international markets, which causes appropriate personnel solutions, both in management and in accounting and cost accounting part. It particularly refers to small and medium enterprises sector, since there still exists mixture of ownership and management.

The largest number of employed on the jobs of accounting and finances (9) assess with an average mark significance of factor Comprehension of management, while the largest number of employed on management jobs (12) assess the same factor with the highest mark (Table 5 and Graph 2).

Graph 2: Distribution of examinees' answers in assessment of factor Comprehension of management considering the type of job

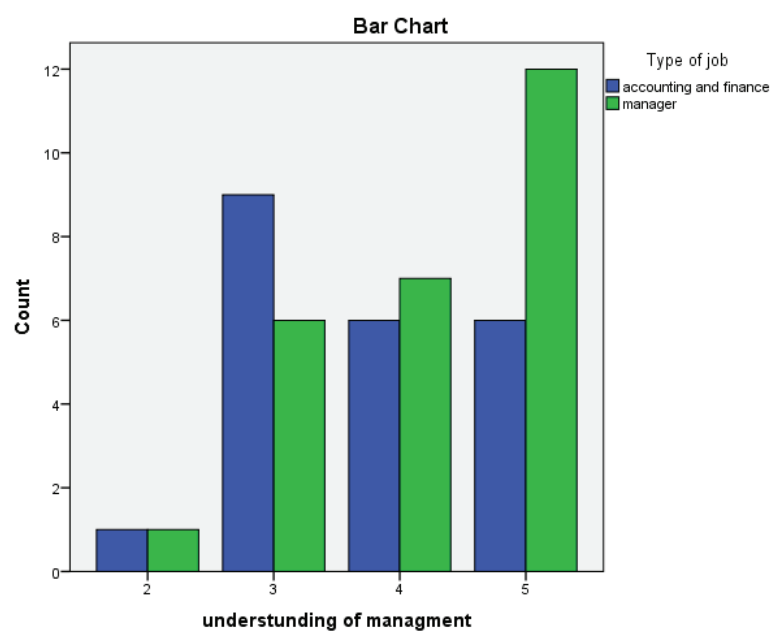

Table 5: Differences between examinees in assessment of the factor Comprehension of management considering the type of job ( $X^{2}$ test)

\begin{tabular}{|c|c|c|c|}
\hline & Value & df & Statistical significance \\
\hline Pearson's & 2.360 & \multirow{3}{*}{3} & 0.501 \\
\hline Kramer's V & 0.222 & \multirow{2}{*}{3} & \\
\hline Contigency coefficient C & 0.216 & & \\
\hline
\end{tabular}

Results show that statistically significant differences $\left(X^{2}=2.360, p>0.05\right)$ in assessment of the factor Comprehension of management considering the type of job that is done by examinee (Table 5). Kramer's indicator is $\mathrm{V}=0.222$, which indicates that small interconnection between variables. The type of job does not affect differences in Comprehension of management, considering that for all variables Sig $>0.05$, along with existence of small interconnection between variables.

Employed on management jobs gave a bigger importance to management's impact on cost management efficiency in comparison with people employed on accounting jobs. For overall enterprise's result, responsibility is on management, hence its role is particularly important in the area of cost accounting, too. Management decides, among other things, on 
accounting policy which enterprise applies in accordance with professional and legal regulations. As far as organization of cost accounting is concerned, cooperation between management and accounting is important in order for cost accounting system to provide relevant and timely information for making business decisions. Those information must be understandable to nonfinancial managers, too, because otherwise communicational gap between these two groups of jobs is created, with a negative impact on cost management efficiency. Because of that, constant education and knowledge improvement of managers and accountants, which are important preconditions for successful management of an enterprise and its competitiveness, are necessary.

The biggest number of employed on accounting and finances jobs (8) assess with an average mark significance of the factor The Impact of competition, while the biggest number of employed on management jobs (14) assess the same factor with the mark 4 (Table 6 i Graph 3).

Graph 3: Distribution of examinees' answers in assessing the factor The impact of competition considering the type of job

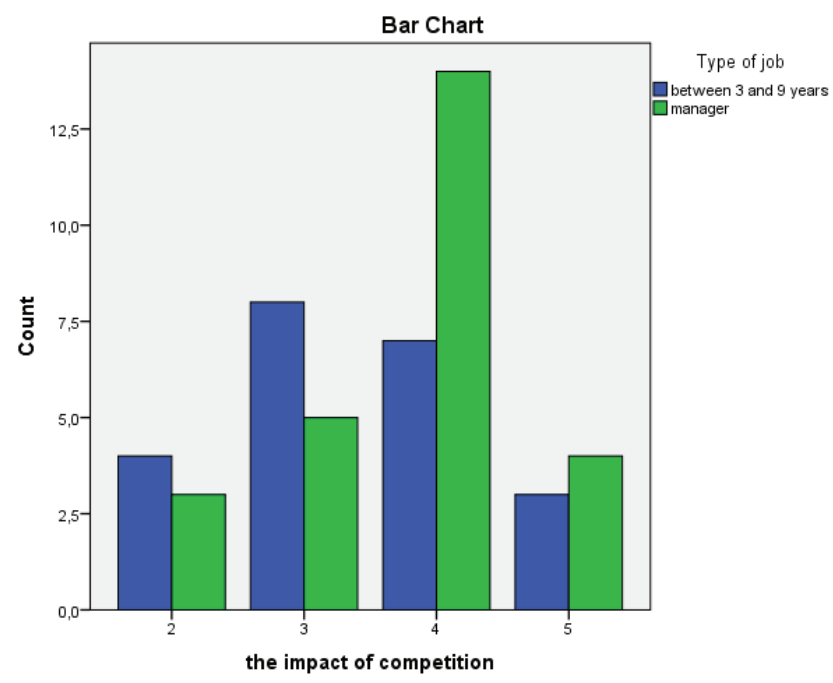

Table 6: Differences in assessment of factor The impact of competition considering the type of job ( $X^{2}$ test)

\begin{tabular}{|c|c|c|c|}
\hline & Value & df & Statistical significance \\
\hline Pirson's $X^{2}$ & 2.999 & & 0.392 \\
\hline Kramer's V & 0.250 & \multirow{3}{*}{3} & \\
\hline Contigency coeficient C & 0.242 & & \\
\hline
\end{tabular}

Obtained results show that statistically significant differences $\left(X^{2}=2.999, \mathrm{p}>0.05\right)$ in assessment of the factor The impact of competition were not determined (Table 6). Kramer's indicator is $\mathrm{V}=0.250$, which indicates small interconnection between variables. The type of job does not affect differences in the impact of competition, considering that for all variables $\mathrm{Sig}>0.05$, along with existence of small interconnection between variables. 
In this research, employed in accounting and finances area gave a smaller importance to the impact of competition on cost management efficiency in comparison with employed on management jobs. Reason for that is the fact that accounting worker observe competition on market significantly narrower than management, which is dealing with it on a daily basis. Competition has a dynamic character with changeable effects during time, it is consisted of both existing and potential competitors, the emergence of substitutes on market, negotiation relations with suppliers and buyers, barriers to enter into the branch of an industry and other. Enterprises are forced to adapt to price that is formed on market and on which they have very small impact. Because of that, adequate attention has to be committed to the questions of studying enterprise's market position, which will, in the long term, result in lower costs in comparison with competition, along with maintenance of quality which is demanded by consumers. The entrance of companies and strong foreign enterprises each day reinforce importance of these factors for survival and growth of domestic enterprises.

The biggest number of employed on accounting and finances jobs (9) assess with the highest mark significance of factor Legal and internal accounting regulations, while the biggest number of empoyed on management jobs (11) assess the same factor with an average mark (Table 7 i Graph 4).

Graph 4: Distribution of examinees' answers in assessment of the factor Legal and internal accounting regulations considering the type of job

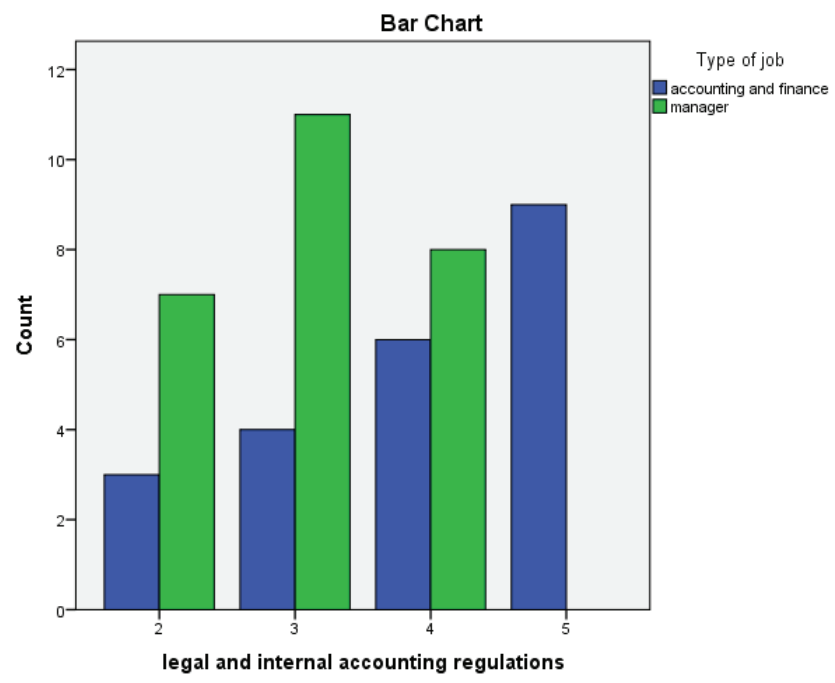

Table 7: Differences in the assessment of the factor Legal and internal accounting regulations considering the type of job ( $X^{2}$ test)

\begin{tabular}{|c|c|c|c|}
\hline & Value & df & Statistical significance \\
\hline Pirson's $X^{2}$ & $\mathbf{1 3 . 9 1 6}$ & \multirow{2}{*}{3} & $\mathbf{0 . 0 0 3}^{\star *}$ \\
\hline Kramer's V & $\mathbf{0 . 5 3 8}$ & & \\
\hline Contingency coeficient C & $\mathbf{0 . 4 7 4}$ & & \\
\hline
\end{tabular}

${ }^{* *} \mathrm{p}<0.01$ 
Obtained results show that statistically significant differences $\left(X^{2}=13.916, \mathrm{p}<0.01\right)$ in assessment of the factor Legal and internal accounting regulations considering the type of the job done by an examinee were determined (Table 7). Kramer's indicator is V $=0.538$, which indicates medium interconnection between variables. The type of examinee's job affects the differences in legal and internal accounting regulations, considering that for all variables $\operatorname{Sig}<0.01$, along with existence of moderate interconnection between variables.

Examinees on management jobs gave a significantly smaller importance to the factor legal and internal accounting regulations in comparison with examinees which are employed on accounting jobs. Such outcome is a result of unrecognition of importance of legal and internal accounting regulations by the enterprise's management. Namely, current regulations have left a lot of space to domestic accounting regulations to create efficient cost accounting system and adapt it to its needs. How much will this regulations provide adequate and timely information for making business decisions depends on the quality of accounting staff. Accounting policy is created by management and accountingfinancial office together, hence their relation has to be based on familiarity with the issues, and on mutual cooperation and confidence. So called communicational gap between management and accounting workers is also noticeable, especially in the small and medium enterprises sector. It is certain that current processes of foreign enterprises arrivals, mergers and acquisitions of smaller enterprises and other, will have a positive effect and raise the quality of internal accounting regulations in Serbia.

\section{Conclusion}

Research in this paper showed that in enterprises in Serbia communicational gap between financial-accounting staff, on one hand, and management, on the other, is present. It is expressed more in small and medium enterprises sector, where ownership and management are often coupled. Those differences are visible in the answers on asked questions about the impact of certain factors on cost accounting efficiency. Employed on the management jobs gave significantly smaller importance to the factor internal accounting regulations in comparison with employed on accounting and finances jobs. Vice versa, financial-accounting staff gave smaller importance to factors the impact of competition and comprehension of management on cost accounting efficiency. Both groups of examinees equally valued factor the competence of accounting staff and its impact on cost accounting efficiency as the basis for making business decisions.

Belated introduction of international standards in Serbia had a reflection on the application of modern cost accounting methods. Besides above mentioned factors, continual education and improvement of internal accounting regulations will have, in perspective, a significant impact on modernization and an increase of cost accounting efficiency. Also, entrance of foreign enterprises on our market affects acceptance and application of positive accounting practice within domestic enterprises. The need for internalization of domestic enterprises and competitiveness' increase on foreign markets will also have a positive impact on cost accounting efficiency's improvement. 


\section{References}

Agrawal, S.P., Mehra, S., Siegel, P. H., (1998): Cost Management System: An Operational Overview, Managerial Finance, 24 (1), p 60.

Antić, Lj., Novićević, B., (2011) Sinergija savremenih koncepata obračuna troškova u funkciji efikasnog upravljanja preduzećem, U Petrović, E. (Ur.) Nauka i svetska ekonomska kriza, str. 399-406, Ekonomski fakultet Niš, .ISBN 978-86-6139-0425 COBISS.SR -ID188481292

Aničić, J., Jelić, M., Đurović, J., Radojičić, S., Prokopović, Ž., (2014). Interni obračun u funkciji donošenja poslovnih odluka, Ekonomika, 60 (1) p. 117-125.

Aničić, J., Popović, S., (2015) Koncept ABC metode, prednosti i ograničenja u primeni, Računovodstvo, Godina 59(3), p. 68-79.

Begović, V., S., Momčilović, M., Tomašević, S., (2018) Economic efficiency assessment of investment, Anali Ekonomskog fakulteta u Subotici, 54(39), p. 187-204.

Cooper, R., Kaplan, R., (1988) „How Cost Accounting Distors Products Costs“ Management Accounting, pp. 20-27.

De Marco, T., (1982) Controling Software Projects, Youordon Press, New York

Groth, J., Kinney, M., R, (1994) Cost Management and Value Creation, Management Decision, 32, (4), p 52-57.

Hammer, L., Carter, W., Usry, M., (1994) Cost Accounting, South-Western, Cincinnati, Ohio, p. 9.

Hilton, W. Ronald, Maher, W. Michael, Selto, H. Frank (2000): Cost Management, Startegies for Business Decisions, International Edition, Irwin \& McGraw-Hill; Boston, $\mathrm{p} 1$.

Horngren, C., Foster, G., Datar, S., (1994) Cost Accounting: A Managerial Emphasis, Prentice Hall, Englewood Cliffs, New Jersey, p. 882.

Janjić, I., \& Ilić, Đ. (2019). Zadovoljstvo poslom kao merilo subjektivnog uspeha u karijeri. Trendovi u poslovanju, 7(1), 49-60.

Kaplan, R., (1988), „One Cost System Isn囚t Enough“, Harvard Business Revew, JanuaryFebruary, p. 64.

Malinić, S., Jovanović, D., (2011) Implementacija integrisanih koncepata upravljanja troškovima u lancu nabavke - strategijski pristup TC I ABC, Računovodstvo, br.11-12, p 29-44

Malinić, D., Milićević, V., Stevanović, N., (2018) Upravljačko računovodstvo, Centar za izdavačku delatnost Ekonomskog fakulteta u Beogradu

Milićević, V., (2000) Računovodstvo troškova i poslovno odlučivanje, Ekonomski fakultet, Beograd, p. 137.

Micić,R.,\&Arsić,L.(2010).Upravljanjeljudskimresursimauorganizacijama.Ekonomski pogledi, (2), 27-40.

Petrović, Z., Stanišić, N., Vićentijević, K., (2015) Priručnik za primenu kontnog okvira za privredna društva, zadruge i preduzetnike, Informativno poslovni centar, Beograd. 
Radović-Marković, M., Salamzadeh, A., \& Vujičić, S. (2019). Selection of organization models and creation of competences of the employed people for the sake of competitiveness growth in global business environment. International Review, (1-2), 64-71.

Todorović, N., (2009) ABC metoda u upravljanju troškovima, Zbornik radova Ekonomskog fakulteta u Istočnom Sarajevu, br. 3, str. 232

Schwalbe, K., (2015)Information Tehnology Project Management, Cengage Learning

Shank, J., Govindarajan, V., (1993) Strategic Cost Management: The New Tool for Competitive Advantage, Free Press, New York

Simonović, Z., Curčić, N., \& Miletić, V. (2017). Some problems of small and medium enterprises in Serbian agriculture. Anali Ekonomskog fakulteta u Subotici, (37), 57-69.

Škrtić, M., (2005) Upravljanje troškovima s ciljem povećanja konkurentnosti, Zbornik radova - Povećanje konkurentnosti i uspešnosti poslovanja, „M.A.K-Golden, Zagreb-Zadar, str. 108.

Wilson, R, Gilligan, C.,(2003) Strategic Marketing Management, Second edition, Elsevier Butterworth Heinemann, Oxford 